Jusmal llmial

PFUR AT DE

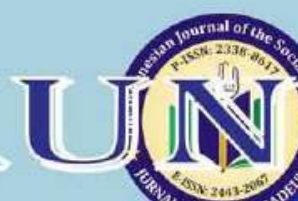

Vol. 5, No. 3, September 2017

$\int_{\substack{\text { Indrjesident } \\ \text { si in }}} 1$

sCAD Intependent Acreditatiou by 100 since 2014 $\bigodot$ Copernicus Publications

\section{JIP}

The Indonesian Journal of the Social Sciences www.journal.scadindependent.ors D01 Prefix Number; 10,26811
Csinta

INDEX COPERNICUS 


\title{
THE ROLES OF MATRILINEAL SYSTEM TOWARDS INTEGRATING RELIGIOUS AND CULTURAL VALUES IN MINANGKABAU COMMUNITY
}

\author{
Ciptro Handrianto \\ Universiti Pendidikan Sultan Idris, Malaysia \\ Contributor Email: handriantociptro@gmail.com
}

Received: April 15, 2017

Accepted: Sep 21, 2017

Published: Sep 28, 2017

Article Url: http://journal.scadindependent.org/index.php/jipeuradeun/article/view/170

\begin{abstract}
This paper looks at one of the unique cultures of Indonesia, the Minangkabau, in West Sumatera Province. Minangkabau is known as one of the biggest cultures in the world practicing matrilineal system in its family. This system means that every child who is born follows his or her mother's clan line. Matrilineal education integrates religious and cultural values to their children. According to this system, there are four central figures that have important roles in educating young generations of Minangkabau. They are Bundo Kanduang, Ninik Mamak, Alim Ulama, and Cadiak Pandai. The purpose of this paper is to explore the roles of these four central figures of Minangkabau in integrating religious and cultural values to the young generation. The data for this paper uses secondary data, namely the study of literature. Data analysis techniques in this study are three roots of reduction, presentation, and verification of data. Results show that each of the four central figures has different roles but they are united to integrate the education system of the Minangkabau community.
\end{abstract}

Keywords: Matrilineal System, Religious, Cultural Values, Minangkabau 


\section{A. Introduction}

Minangkabau has a unique culture by practicing matrilineal system in its family's clan line. Metje (1995:23), West Sumatra Province is the homeland of the Minangkabau community. They form the largest matrilineal society in the world. According to recent statistics in the census (Badan Pusat Statistik, 2010), there are more than four million Minangkabau who reside in West Sumatra but millions also live in other areas, called rantau.

The Minangkabau young generations have been growing and developing for a long time in this system. The matrilineal system is the name for the culture in general but when we talk about how education is going on in Minangkabau society, it is known as matrilineal education. Matrilineal education means that the learning of children is conducted not only by the parents (father and mother) but also by matrilineal family. Stark (2013), the life in the core areas were defined by a matrilineal way of life. This means there are certain kinship groups which follow the female descent of a mother. The woman's brother is responsible for her children rather than her husband.

Meanwhile, a husband lives with his wife's family, the educational process for the children is under mother and her relatives' authority, especially her brothers (mamak). Mamak will teach the children how to maintain the culture because he has directly got duties from his ancestors to guide his clan. Children in this term called "kamanakan" will accept the clan properties from mamak and they will be trained how to be the good leaders in their clan.

The mothers always communicate the important events to their brothers (mamak). They will ask the opinion of mamak for instance where the best place to their children for pursuing their study is. Mamak is also involved in deciding the marriage of kamanakan, and many other aspects.

Even though mamak and mother are the main actors in matrilineal education, children in Minangkabau are controlled by many figures in their community. Minangkabau young generation cannot say "who are you, why you intervene me, and this is not your business" to other people 
because they come under the strong relative relations even their father or mother's friends.

The Minangkabau community will maintain its survival as long as religious and cultural values are convincingly integrated to the children. The attention for integrating the values is the duty of community's structures under matrilineal education. It means that this system must encourage generations to practice Islam and culture in an integral way.

Islam has a long history in Minangkabau society and makes the closest relation to the adat (custom). In its development, Islam and culture cannot be separated each other in Minangkabau community and both of them have mutual relations. Minangkabau culture has a basic philosophy to show this relation known as "adat basandi syarak, syarak basandi kitabullah". It means that the adat (custom) is based on religion and religion is based on Al Quran (the holy book of Islam). This philosophy shows that between culture and religion doesn't have a contradiction and must be integrated into community's rules.

So it can be presumed that these panghulu (ninik mamak) decided what they accepted. Step by step the Islamic elements entered the adat side. For example, the clans started to consider more the Islamic values and therefore the children should get an Islamic education in the surau (prayer houses) (Radjab, 1995). Panghulu as the cultural leader fully supports religious activities and give strengthening to his clan or kamanakan actively participating to religious activities.

In the matrilineal system of Minangkabau, there are four central leadership figures that have responsibilities to educate young generations. These elements are: bundo kanduang, ninik mamak, alim ulama, and cadiak pandai. Each of them has different duties but they cannot be separated to ensure the system working well. The purpose of this paper is to explore the roles of these four central figures of Minangkabau in integrating religious and cultural values to the young generation.

\section{B. Method}

This paper used qualitative approach to understand social facts and analyzed phenomena systematically that happened in society. It 
could be explained that this approach was the problem solving procedures that were investigated by describing the conditions of subject or object (a person, institution, community, etc) currently and was based on real facts (Nawawi, 2012). In this term, the author collected social data about matrilineal system phenomena in Minangkabau and classified the roles of structural figures in community system for educating young Minangkabau generation.

The attitudes of the four central figures were understood by regarding to the way they integrated religious and cultural values to the young children. Patton (2009) insisted that meaning and attitudes are the important points for human research and cultural social contexts, including developing emphatic understanding based on subjects`experiences and their understanding between personal perception and attitudes.

There are two types of data based on how to get them. Those are primary and secondary data. Primary data were gained directly from respondents by using interview, observation, and test. Secondary data or indirectly collected data came originally from books, literatures, theory documentations, concepts, and reading sources (Sugiyono, 2004). For this study, the author used secondary data. The author took data from accurate resources related to matrilineal system in Minangkabau community and showed the research findings about this system by other writers.

The data for this paper used secondary data, namely the study of literature. Data collected in qualitative research are not in nominal numbers form but they are formed in words, pictures, and records (Moleong, 1988). To construct the ideas of this paper, it was supported by the relevant literatures. Many researchers have been conducting the study about Minangkabau community and the results were used by the author to strengthening the paragraphs. The writer elaborated many resources such as books, journals, and official statistic data to achieve the purposes of the study.

Data analysis techniques in this study were through three roots of reduction, presentation, and verification of data. According to Miles and Huberman in Silalahi (2010), qualitative data can be analyzed by three grooves occurring simultaneously. The first stage is data reduction, through 
the electoral process, focusing on simplification, abstraction and transformation of raw data that emerged from hand written notes. The group data in final conclusions can be drawn and verified. The second stage is presentation, data with a set of structured information that gives the possibility of drawing conclusions and taking action. The third stage is verification as short as rethinking that came to mind analyzer, and a review to develop intersubjective agreement.

In writing process, the author used systematically steps to integrate the ideas for gaining the purposes of the study. The first step was briefly overview or introduction about the topic. The second step was exploring the matrilineal system in Minangkabau community. The information was collected from data and deep analytical of social phenomena. The third step was to analyze the roles of four central figures, bundo kanduang, ninik mamak, alim ulama, and cadiak pandai in Minangkabau. For the next step, the writer explored the roles of matrilineal education in integrating religious and cultural values to the young children by looking at each function of the central figures. Meanwhile in the last step, the results would be concluded and were given recommendations.

\section{Research Finding and Discussion}

\section{Matrilineal System in Minangkabau Community}

Matrilineal system is the symbolic recognition that a mother is the central point for unity. Minangkabau people give the privilege rights for women because they do three functions while the men couldn't do, such as pregnancy, childbirth, breastfeeding for the baby. These things cause a baby is always close to his or her mother even though in limited condition the mother never lets her baby suffering.

In matrilineal cultures relative's membership is traced through the uterine line, so that children belong to the mother's kinship and not to their father's. A man's heirs are thus his sisters' children, not his own (La Ferrara, 2007). The mother's family has the important rules that must be followed by the young children. Identity of generations is determined by their mother's clan. A father also has great responsibility to guide his sister's sons or daughters. 
When a mother has authority in ownership all the properties of her clan, she cannot ignore the functions of mamak (his brothers) in her family's life. The mother will be helped by her brothers in farming system to teach her sons identifying their lands and administering the property. Therefore, David (2011) affirmed even though women (in the matrilineal system) play a big role in owning, controlling and managing, they play a minor role in working on the land. It means that the transfer of knowledge in traditional farming systems passes from father to son or farther to nephew in matrilineal systems, too.

The mother teaches daughters in kitchen activity and together they cook for preparing meal to the men who work on their land. The girls or daughters in Minangkabau should have expertise in cooking because it is a symbol of dignity. In the past time, this ability was one of the some requirements by a man looking for his future wife. It may be a causing Rendang Padang made by Minangkabau women being distinguished food around the world today.

In Minangkabau Matrilineal System, it is also known the term of induak bako jo anak pisang for describing relation between children and their father's relatives. Induak bako means the father's family and anak pisang is the calling for daughters or sons of a brother. This relation as the evident, even though children are under mothers rule, father's family has also given contribution. Induak bako plays important role to its anak pisang starting from baby born, sunnah rasul (circumcision), marriage, and mourning ceremony. Sometimes, it will be a big trouble if the children don't have induak bako that means that their mother married to a man from outside Minangkabau. In another side, if Minangkabau man married to other girl from outside, his children considered don't have any clan at all. The pure relation induak bako and anak pisang naturally happens in both man and woman coming from Minangkabau culture.

In term of Minangkabau community learning, there is a glorious philosophy believed by many people known as alam takambang jadi guru. It 
means that the wide nature can be the teacher. In larger meaning, everything that happens in environments can be learned. The children should get the positive values from the nature. They have to develop their experience and knowledge by exploring the natural or social phenomena. Minangkabau community opens opportunities for generation to debate politely in encouraging their critical thinking. Parents feel mandatory to send their children to surau for learning Qur'an. After reciting Quran, the ulama and cadiak pandai will teach them how the knowledge is very important to our life and it is part of the religious orders. The effects of this philosophy are many Minangkabau generations looking for knowledge by visiting many places in far distance from their motherland and many of them to be prominent persons in rantau (the areas outside from Minangkabau).

For leadership aspects, matrilineal system has four central figures that have big duties in controlling sustainable community. They are bundo kanduang, ninik mamak, alim ulama, and cadiak pandai which each of them has certain functions especially in educating young generation. They are community`s structures that have authorities for guiding their kaum (clan) and in practicing their job, they cannot be separated each other. The children education in Minangkabau not only is the right of mother's relatives but it also involves the four central figures.

\section{The Roles of Four Central Figures in Matrilineal Education}

There are four central figures in matrilineal system in educating young generation of Minangkabau. Each of them has specific duties to maintain the religious and cultural values in society. They are formed from community`s structures known as bundo kanduang, ninik mamak, alim ulama, and cadiak pandai.

\section{a. Bundo Kanduang}

Bundo kanduang represents of mothers in Minangkabau matrilineal system who is a land owner. Assisted by her brothers, she controls all the properties to use in fulfilling the family needs. She is a non formal leader in 
society as the symbol that man and woman in Minangkabau have the equal rights. An event can be canceled if bundo kanduang doesn't give her approval.

As a mother, bundo kanduang has the closest relation to the children because every child who was born will follow her clan`s line. She develops attitudes, characters, and values to the children about how to be a good future Minangkabau generation.

David (2011) found in his research that the mother has the role teaching her daughters how to cook, and it is a sources of shame in the Minangkabau 's culture if a girl cannot cook well. The challenge of today is the decreasing time for interactions between mother and daughters (observation, teaching). For approaching young women in Minangkabau, bundo kanduang involves them in same activities such as cooking, sewing, and preparing family needs. Currently, the interactions between mother and daughter face difficult times because a girl has many activities outsides but anything happened the girls cannot avoid their role as the main component to maintain the family's clan line.

\section{b. Ninik Mamak}

Ninik mamak called penghulu is a central figure leader in Minangkabau's clan. He is respected by community because of his character`s appearance. He devotes himself to maintain adat and preserves all the matrilineal properties. The appearing problems in matrilineal system will be solved by ninik mamak.

For solving problems, ninik mamak consistently emphasizes musyawarah mufakat (discussion and consensus) in democratic system to avoid friction amid community. He looks for the roots of problems and interprets before doing discussion. He is a wise man because people are easy to accept and understand his explanation. Although he doesn't support conflict to other clans, he cannot be silent if he thinks something unfair and is harmful to his clan rights. He will stand to ensure the safety of his clan.

In general role, ninik mamak is the clan leader that he has authority to keep the culture and develops his clan. In conducting the duties, he must be aware that he has a family, so he should make balance between 
an husband and clan`s leader. Gani (2002:94) persisted whereas in practice of the daily life, a ninik mamak has an obligation to the children, nephew, clan, and nagari (small area for Minangkabau community).

\section{c. Alim Ulama}

Islam is an official religion in Minangkabau and many aspects of community`s` lives are regulated by the religious law explained by Alim ulama. Alim ulama is recognized as the person who has deep understanding about religion and he decides something permitted or not permitted based on Qur`an. He is a central figure in religious matter and is invited in every ceremonial adat. According to Gani (2002), alim ulama is more functioning to develop faith and morality of nagaris young generations, and he is not only for his clan but he also devotes to a large community. The characteristic of his service is all sides of lives.

In adat term, ulama is called "suluah bendang dalam nagari" that it means the light of community. People honor him as person who knows about the religious laws and he can solve wisely the community problem based on his knowledge. For balancing afterlife faith, alim ulama emphasizes that god has the great power in this universe behind everything and human have to follow the right ways to gain the god blessing. He encourages community to war the foolishness because it means the darkness and he boosts young children for pursuing experience, knowledge, and skills because they are the true brightness.

\section{d. Cadiak Pandai}

Cadiak pandai consists of intelligent persons in the Minangkabau and they are part of change makers for better condition. They develop critical and analytical thinking to contribute themselves into community building. Amir (2001: 182) defined that cadiak (clever) in Minang`s people term is the ability to use creative thinking facing complicated circumstances. It is closely related to the mind or intelligence of the brain. Referring to Hakimy (1997:187) cadiak is the knowledge about characteristic of community for 
achieving the perfect goal. Meanwhile, pandai is closely related to a person's professional skills. So cadiak pandai are smart people that have the ability to solve complicated problems, and have professional skills to support their economic life.

Minangkabau philosophy for cadiak pandai is "tahu dek rantiang nan ka mancucuak, tahu dek dahan nan ka maimpok". It means that they have an expertise to predict about what possibly will happen in the future regarding their fabulous knowledge and they quickly give an alert signs if something carries up dangerous to the community. To proof sharpening sensitivity, they have ability to read body languages, facial expressions, and other non verbal communications. Not only can they predict the situations but they also issue recommendations for facing the problems by using constructive solutions.

\section{Matrilineal Education to Integrating Religious and Cultural Values}

Matriliny is the basis of Minangkabau adat. The mother has the central role in the education, affective life, economic security and prosperity of the family. Minang people are always quoting the aphorism, Adat basandi syarak, syarak basandi kitabullah, meaning Adat is based on Islamic law and Islamic law is based on the Qur'an. Adat and Islam are perceived to 'follow complementary paths' but together form 'an inseparable unity' (Abdullah 1971:5). Matrilineal system creates a form of integrating religious and cultural values by empowering the roles of four central figures in educating young children in Minangkabau.

The philosophy has been adopted by the bundo kanduang, ninik mamak, alim ulama, and cadiak pandai to conduct their duties amid community. Religion and adat should be combined to integrating core values to maintain their system. Each of the four central figures has different roles but they are united to integrate the education system of the Minangkabau community. Integrating religious and cultural values are hoped giving positive impacts to the young generation of Minangkabau to keep their identity's survival. 


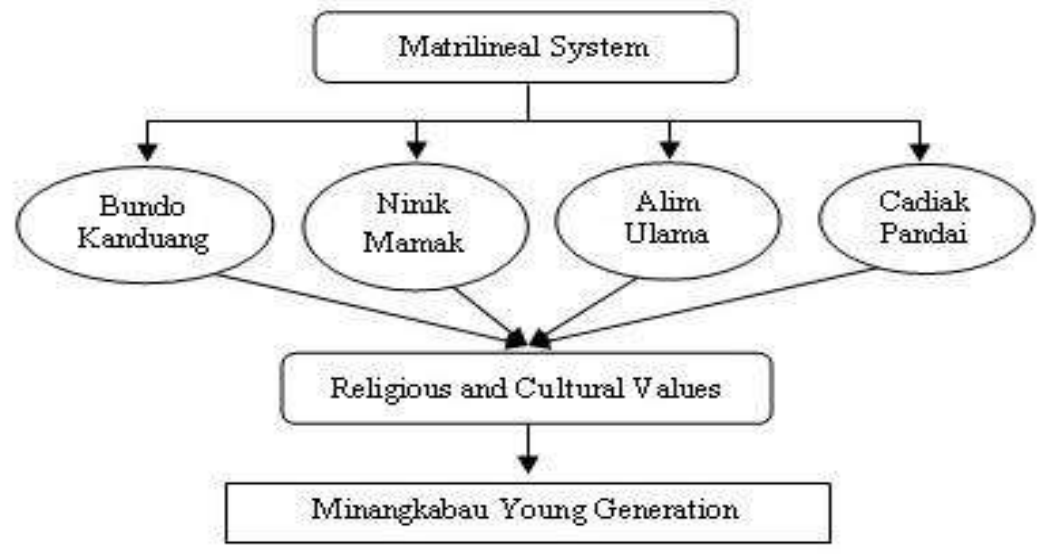

Flowchart 1. Matrilineal Education in Minangkabau

Bundo kanduang is a 'mother' who gives basic learning to her children. For integrating the values, she conducts learning process by knowing who has created us. This is the basic values introduced by mother about exiting of god. Minangkabau people believe that having obedient children will safe them in this world and upcoming eternal live. It will be main education in a family by supporting children in religious learning. She also encourages sons for learning about their properties and do the job. She wants the children not only expert in school lives but also have the life skills, especially in farming system. In cooking aspect, serving and preparing foods for the family are the dignity of Minangkabau women. Training for cooking has been started by bundo kanduang since the daughters still young.

Ninik mamak is a central figure in the clan who has responsibility towards maintaining the richly cultural heritage. Young children are educated by ninik mamak regarding how to encourage them for understanding cultural values. Ninik mamak uses leadership approaches in managing his clan's characters by empowering kamanakan. He shows dignity and model to the children based on ancestors` legacy. He creates and assimilates democratic climates to young children in forming an appropriate policy to their clan.

Alim ulama is an expert in Islamic law as the official religion of Minangkabau. In educating young children, alim ulama uses surau as the place 
for learning process. He teaches them to recite Quran and religious knowledge. He supports the young children in character building. For Minangkabau people, surau can be utilized for many activities such as training adat poems, debating issues, telling the stories, discussing community problems, and preparing for local or national great events. Sometimes, men young children sleep there because they don't have a room at home.

Cadiak pandai train young children to develop their critical analytical thinking. They actively be involved in solving the community`s problems because of their opened mind. Young generations learn how to be the smart people by deeply understanding about their environment. The interaction between cadiak pandai and young children will appear the new concepts for building community. The development of science and technology changes many aspects in the clan of Minangkabau especially the life styles of young children but cadiak pandai do the hard efforts to maintain the core values of community amid their limited conditions.

This system has been implemented in the community rules of Minangkabau's families. The four central figures encourage generation to open their mindset without leaving the community's core values. They have been taught since the early childhood to understand about their self existence as much as they can. The result of this system creates the unique character of young generation of Minangkabau especially for the men's life styles. They go around the world and many parts of Indonesia in young ages called by "marantau" because they are suggested to be the survivors. In rantau, they create many things as merchants, academicians, even political figures. In Indonesia, many outstanding persons were born from this system like Buya Hamka, Bung Hatta, Agus Salim, Tan Malaka, Sutan Syahrir, Muhammad Yamin, etc. Minangkabau figures always fill in the seats of every presidential cabinets of Indonesia and some of them teach in many national and international universities.

\section{E. Conclusion}

This paper has looked at the matrilineal system in Minangkabau society and tried to answer how the roles of matrilineal central figures 
integrate religious and cultural values for the young generation of Minangkabau. The answer was that the four central figures, bundo kanduang, ninik mamak, alim ulama, and cadiak pandai have integrated the values in maintaining their identity. Based on this study, this paper advises that the government should give full attention towards preparing teachers in formal teaching situation by teaching pedagogy that integrates and assimilates the matrilineal system of education in Minangkabau.

\section{Bibliography}

Abdullah, Taufik. (1971). Schools and Politics; The Kaum Muda Movement in West Sumatra (1927-1933). Ithaca, NY: Cornell Modern Indonesia Project, Cornell University.

Amir MS. (2001). Adat Minangkabau: Pola dan Tujuan Hidup Orang Minang. Jakarta: PT. Mutiara Sumber Widya.

Badan Pusat Statistik (n.d.). Penduduk Indonesia Menurut Provinsi 1971, 1980, 1990, 1995, 2000 dan 2010. (http:/ / www.bps.go.id/tab_sub/view.php?kat=1\&tabel=1\&daftar $=1 \&$ id_subyek=12\&notab=1, accessed April 4th 2017).

David, W., \& Ploeger, A. (2011). Role of Matrilineal System, Gender and Education in Traditional Farming Systems and Food Culture in West Sumatra Indonesia. Proceedings of 17th IFOAM Organic World Congress, September.

Gani, Rita. 2002, Tungku Tigo Sajarangan: Analisis Model Komunikasi Kelompok dalam Interaksi Pemimpin pemerintahan di Sumatera Barat. (tesis). Bandung.

Hakimy, Idrus Dt Rajo Penghulu. (1997). Pokok-Pokok Pengetahuan Adat Alam Minangkabau. Bandung: Penerbit Remaja Rosda Karya.

Hughes, K. J., \& Batten, L. (2016). The Development of Social and Moral Responsibility in Terms of Respect for the Rights of Others. Jurnal Ilmiah Peuradeun, 4(2), 147-160.

La Ferrara, Eliana (2007): Descent Rules and Strategic Transfers: Evidence from Matrilineal Groups in Ghana. Journal of Development Economics, 83: 280-301. 
Metje, U. M. (1995). Die Starken Frauen. Gespräche Über Geschlechterbeziehungen bei den Minangkabau in Indonesien. Frankfurt/ New York: Campus Verlag.

Moleong, Lexy J. (1988). Metodologi Penelitian Kualitatif. Jakarta: Proyek Pengembangan LPTK.

Nawawi, Hadari. (2012). Metode Penelitian Bidang Sosial. Yogyakarta: UGM Press.

Patton, Michael Q. (2009). Metode Evaluasi Kualitatif. Yogyakarta: Pustaka Pelajar.

Radjab, M. (1995). Village Childhood (The Autobiography of a Minangkabau Child). In S. Rodgers (ed.), Telling Lives, Telling History. Autobiography and Historical Imagination in Modern Indonesia (pp. 149-324). Berkley/Los Angeles/London: University of California Press.

Silalahi, Ulber. (2010). Metode Penelitian Sosial. Jakarta: Refika Aditama.

Stark, A. (2013). The Matrilineal System of The Minangkabau and Its Persistence Throughout History: A Structural Perspective. Southeast Asia A Multidisciplinary Journal, 13, 1-13.

Sugiyono. (2004). Metode Penelitian Administratif. Bandung: Alfabeta. 